\title{
A study on the social reproduction conditions of nursing undergraduates of two universities in São Paulo
}

\author{
Estudo das condições de reprodução social de graduandos de \\ enfermagem de duas universidades paulistas \\ Estudio de las condiciones de reproducción social de estudiantes \\ de enfermería en dos universidades de São Paulo
}

How to cite this article:

Campos CMS, Dias VFG, Otrenti E, Pascon DM, Meireles E, Mira VL. A study on the social reproduction conditions of nursing undergraduates of two universities in São Paulo. Rev Esc Enferm USP. 2020;54:ee03570. doi: https://doi.org/10.1590/S1980-220X2018052103570

\section{Celia Maria Sivalli Campos ${ }^{1}$ \\ D) Vania Ferreira Gomes Dias ${ }^{1}$ \\ Eloá Otrenti ${ }^{1}$ \\ Daniela Miori Pascon² \\ Everson Meireles ${ }^{3}$ \\ Vera Lúcia Mira ${ }^{4}$}

${ }^{1}$ Universidade de São Paulo, Escola de Enfermagem, Departamento de Enfermagem em Saúde Coletiva, São Paulo, SP, Brazil.

${ }^{2}$ Pontifícia Universidade Católica de São Paulo, Faculdade de Ciências Médicas e da Saúde, Sorocaba, SP, Brazil.

${ }^{3}$ Universidade Federal do Recôncavo da Bahia, Centro de Ciências da Saúde, Santo Antônio de Jesus, BA, Brazil.

${ }^{4}$ Universidade de São Paulo, Escola de Enfermagem, Departamento de Orientação Profissional, São Paulo, SP, Brazil.

\begin{abstract}
Objective: To identify the social reproduction characteristics of nursing undergraduates. Method: A quantitative descriptive cross-sectional study conducted in two undergraduate degree courses in nursing, one public and one private, in the state of São Paulo. Results: There were 285 students who participated, with 195 from the public university and 90 from the private one, who answered a questionnaire to classify social reproduction profiles. Four groups with different social conditions were identified. Although most families had stable living conditions, the percentage of families with poor working and living conditions was not negligible. Conclusion: The analysis on the social reproduction of the families of undergraduate students of the two courses exposed stability gradients which are compatible with intermediate social strata.
\end{abstract}

\section{DESCRIPTORS}

Students, Nursing; Social Class; Social Conditions; Education, Higher.

Av. Dr Enéas de Carvalho Aguiar,

419, Cerqueira César

CEP 05403-000 - São Paulo, SP, Brazil Received: 12/14/2018

eloaotrenti@usp.br 


\section{INTRODUCTION}

Higher-level academic courses (at least most of them) do not consider the heterogeneity of undergraduate social conditions; therefore, they plan teaching based on the principle of student body homogeneity, which is considered because of the students' choice for the same course and for having been selected by a similar filter - the college entrance examination. However, social origin is directly associated with school trajectory ${ }^{(1)}$.

With the implementation of federal inclusion policy guidelines contained in the National Education Plan, there was an increase in the number of first-year students who are historically excluded from higher education. As a result, there was an increase in social diversity as identified by analyzes of socioeconomic questionnaires which are now systematically applied to first-year students and graduates ${ }^{(2)}$.

The systematization of these results has enabled studies to identify social profiles of undergraduate students through demographic and socioeconomic data, which classify them into social strata ${ }^{(3)}$. Some studies have related socioeconomic variables with the choice of courses/ career and academic performance ${ }^{(1,4)}$, resulting in social differences becoming visible among higher education students and their implications for the education process.

Since students' social conditions are in the basis of their learning process, it is essential to recognize them for an evaluation of the contradictions of the teaching-learning process as a way to organize and implement curricular changes which promote emancipatory educational practices $^{(5)}$.

The social reproduction conditions of the students are determined by their social class position. As a consequence, the families' work insertion is diverse and unequal, which result in unequal access to socially produced goods, meaning in unequal living conditions. The relations between the subjects therefore are relations between social classes and the reproduction of social life occurs through the reproduction and maintenance of these classes $^{(6)}$.

From these considerations, it was assumed that including in this study students from two universities, one public and one private, would favor greater diversity of social reproduction characteristics.

The aim of the study was to identify the social reproduction characteristics of nursing undergraduate students' families.

\section{METHOD}

STUDY DESIGN

This is a quantitative cross-sectional descriptive study.

\section{SCENARIO}

This study was conducted in two undergraduate degree courses in nursing. One public course was intentionally selected in the city of São Paulo, which we now call the Capital Course (CC), and another private from the interior of the state of São Paulo, which we call the Interior Course (IC). It is noteworthy that these institutions are universities with strict selection criteria for admission.

\section{DATA COLLECTION}

Data collection was performed through a questionnaire applied to identify the social reproduction conditions of nursing students. This questionnaire was elaborated from the Social Reproduction Index (SRI), an instrument used in different contexts to classify social groups ${ }^{(7)}$, according to the characteristics of social reproduction of individuals and families in the production (insertion at work) and consumption (access to socially produced goods) dimensions.

The SRI consists in identifying the head of the family and a set of variables which assess the production dimension related to the work of the responsible: preparatory course for work, occupation classification; and the consumption dimension, with its variables being related to the living conditions of the families: the property of the residence where the family lives, if he/she receives a water bill, electricity, property tax (In Portuguese: IPTU), access to public sewage service, if any family member attends religious services for leisure, and the number of rooms they sleep in.

Classifying the occupation of the head of the family household was performed by the researchers from a detailed description of the function of the household head by the respondents in relation to the performed activity and the employment bond, starting from the Brazilian Classification of Occupations (CBO) $)^{(8)}$.

Occupations such as doctors, dentists, higher education teachers, lawyers, bosses and supervisors, principals, and entrepreneurs are all part of planning and organizing occupations in the CBO. In the group of qualified occupations in execution are technicians in data analysis, accounting and nursing. Semi-qualified workers include nursing assistants, shop clerks, cooks and hairdressers. Among the non-qualified in execution are store or supermarket stockers, street traders, wall painters and gas station attendants. There are also poorly defined occupations which do not fit into any of the occupational groups defined by the CBO.

In addition to the questions which enabled classifying families, a question was added to identify if undergraduates received any financial aid from universities.

\section{DATA ANALYSIS AND PROCESSING}

Characterizing the social reproduction conditions of the families was performed through an analysis of variables and summing the points attributed to these variables. Therefore, the SRI varies depending on the scores obtained.

These scores classify families into four social groups with distinct social reproduction characteristics, starting from Group I (Gl) with higher scores in the analysis of the 
variables, and therefore with more stable working conditions and consequently more stability in the conditions; and up to the most precarious conditions with the lowest scores being found in Group IV (GIV). The SRI identifies the heterogeneity of these groups and exposes the gradients of stability, characterizing social strata within each of the four social groups.

The information collected was organized in a database built with the Microsoft Excel ${ }^{\circ}$ program; each family's SRI was generated and they were classified into the social group corresponding to the achieved value. The data were subsequently analyzed using descriptive statistics.

\section{ETHICAL ASPECTS}

The research was approved by the Research Ethics Committee of the Capital Course, with favorable opinion no. 1.075.039, on May 18, 2015; based on this consubstantiated opinion, the Interior Course also authorized the research. It followed the precepts of Resolution No. $466 / 12$ of the National Health Council on research with human beings. An invitation to participate in the study was performed by the researchers to all students present in the classroom on the days of data collection; those who agreed to participate signed an Informed Consent Form after receiving all instructions.

\section{RESULTS}

Data collection took place between August and December 2015 in both Universities through a questionnaire. There were 280 students enrolled in the CC, and 207 of them participated in the study. However, 12 questionnaires were excluded because they did not contain all the requested answers. There were $125 \mathrm{stu}-$ dents enrolled in the IC, of which 96 participated in the research, but six were excluded for failing to properly fill out the questionnaire.

Thus, 285 students participated, which corresponds to $70.4 \%$ of all undergraduates enrolled in both institutions. There were 195 of the 285 student respondents from the CC and 90 from the IC $(68.4 \%$ and $31.6 \%$, respectively).

The population of 285 nursing undergraduates is demographically characterized in Table 1.

Table 1 - Series, age and gender of respondents, by Higher Education Institution - São Paulo, SP, Brazil, 2015.

\begin{tabular}{lccc}
\hline & \multicolumn{1}{c}{ CC } & IC & TOTAL \\
\cline { 2 - 4 } & $\mathrm{N}(\%)$ & $\mathrm{N}(\%)$ & $\mathrm{N}(\%)$ \\
\hline Serie & & & \\
1 & $62(31.8)$ & $26(28.9)$ & $88(30.9)$ \\
2 & $44(22.6)$ & $23(25.6)$ & $67(23.5)$ \\
3 & $48(24.6)$ & $21(23.3)$ & $69(24.2)$ \\
4 & $41(21.0)$ & $20(22.2)$ & $61(21.4)$ \\
\hline Age & & & \\
Up to 19 years & $49(25.1)$ & $17(18.9)$ & $66(23.2)$ \\
20 to 25 years & $130(66.7)$ & $41(45.6)$ & $171(60.0)$ \\
Over 25 years & $16(8.2)$ & $32(35.6)$ & $48(16.8)$ \\
\hline
\end{tabular}

\begin{tabular}{lccc}
\hline Gender & & & \\
Female & $176(90.3)$ & $82(91.1)$ & $258(90.5)$ \\
Male & $19(9.7)$ & $8(8.9)$ & $27(9.5)$ \\
\hline Total & $195(100)$ & $90(100)$ & $285(100)$ \\
\hline
\end{tabular}

Note: CC = Capital Course; IC = Interior Course.

The table above shows the expected predominance of females in undergraduate nursing courses, the age corresponds to the expected age range in undergraduate courses and the highest participation of first year students.

The SRI application identified four groups with different social conditions (GI, GII, GIII, GIV), presented in Table 2.

Table 2 - Social groups, according to Higher Education Institution - São Paulo, SP, Brazil, 2015.

\begin{tabular}{lccc}
\hline & CC & IC & TOTAL \\
\cline { 2 - 4 } & $\mathrm{N}(\%)$ & $\mathrm{N}(\%)$ & $\mathrm{N}(\%)$ \\
\hline I & $122(62.6)$ & $61(67.8)$ & $183(64.2)$ \\
II & $54(27.7)$ & $21(23.3)$ & $75(26.3)$ \\
III & $10(5.1)$ & $3(3.3)$ & $13(4.6)$ \\
IV & $9(4.6)$ & $5(5.6)$ & $14(4.9)$ \\
\hline Total & $195(100)$ & $90(100)$ & $285(100)$ \\
\hline Note: $C$ C $=$ Capital Course; IC = Interior Course. &
\end{tabular}

The distribution of student families into the four social groups was proportionally similar in both educational institutions, which expresses similar social conditions. The majority of families in both institutions were classified into $\mathrm{Gl}$, the percentage of families classified into Gll of CC was twice lower than in $\mathrm{Gl}$, and the percentage of families in GII in the IC was 2.5 times lower than the percentage of families in the Gl. The percentages in the GIII and GIV groups of both institutions were low. The percentages of GIII and GIV groups of the CC added up to $9.7 \%$ of the total families, while the sum of the percentages in the IC was $8.9 \%$.

The results in the tables are presented into the four social groups (GI, GII, GIII and GIV), even when the number of representatives is small, in order to contemplate the social heterogeneity found in the studied population.

The people recognized by students as responsible for their families are shown in Table 3.

Most CC students (87.7\%) answered that they lived with the head of the household. The same answer was given by $96.7 \%$ of the IC. The highest percentages of family heads were parents in the four social groups of the CC, while this percentage in the IC was only higher in the $\mathrm{Gl}$. Among those responsible for the families of the IC, there was a predominance of mothers in the GIl, partners/ spouses in the GIII, and the actual graduates stood out in the GIV, which characterizes a lower stability potential in relation to CC families.

The occupational characteristics of those responsible for the families stand out. Of these, $63.2 \%$ had occupations which required university, technological or technical preparatory courses (data not shown in table). 
Almost all of those responsible with a preparatory course for work were found in Group I, for both CC (38.2\%) and IC (18.9\%) (data not shown in table).

Insertion of the family head in the time of work production varied according to the qualification and specificity of the occupation performed, being described according to the $\mathrm{CBO}^{(8)}$, determining various ways of working as shown in Table 4.

Table 3 - Relationship with family heads by social group, according to Higher Education Institution - São Paulo, SP, Brazil, 2015.

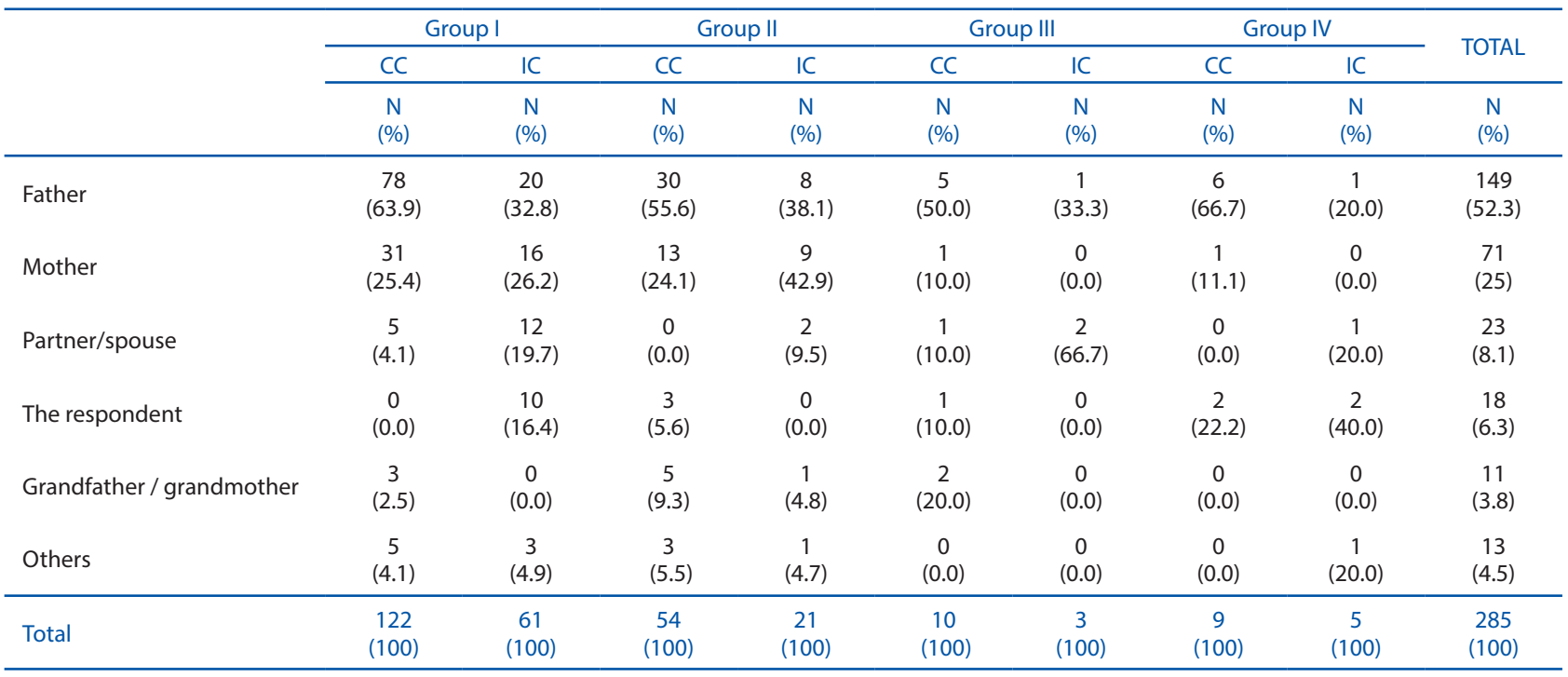

Note: $C C$ = Capital Course; IC = Interior Course.

Table 4 - Classification of the household head occupation according to social group and Higher Education Institution - São Paulo, SP, Brazil, 2015.

\begin{tabular}{|c|c|c|c|c|c|c|c|c|c|}
\hline \multirow{3}{*}{ Classification of occupation } & \multicolumn{2}{|c|}{ GI } & \multicolumn{2}{|c|}{ G II } & \multicolumn{2}{|c|}{ G III } & \multicolumn{2}{|c|}{ GIV } & \multirow{3}{*}{$\begin{array}{c}\text { Overal } \\
\text { total } \\
\mathrm{N} \\
(\%)\end{array}$} \\
\hline & $\mathrm{CC}$ & IC & $\mathrm{CC}$ & IC & $\mathrm{CC}$ & IC & $\mathrm{CC}$ & IC & \\
\hline & $\begin{array}{l}\mathrm{N} \\
(\%)\end{array}$ & $\begin{array}{c}\mathrm{N} \\
(\%)\end{array}$ & $\begin{array}{l}\mathrm{N} \\
(\%)\end{array}$ & $\begin{array}{c}\mathrm{N} \\
(\%)\end{array}$ & $\begin{array}{l}\mathrm{N} \\
(\%)\end{array}$ & $\begin{array}{l}\mathrm{N} \\
(\%)\end{array}$ & $\begin{array}{c}\mathrm{N} \\
(\%)\end{array}$ & $\begin{array}{l}\mathrm{N} \\
(\%)\end{array}$ & \\
\hline Planning and organization & $\begin{array}{c}41 \\
(33.6)\end{array}$ & $\begin{array}{c}12 \\
(19.7)\end{array}$ & $\begin{array}{c}1 \\
(1.9)\end{array}$ & $\begin{array}{c}0 \\
(0.0)\end{array}$ & $\begin{array}{c}1 \\
(10.0)\end{array}$ & $\begin{array}{c}0 \\
(0.0)\end{array}$ & $\begin{array}{c}1 \\
(11.1)\end{array}$ & $\begin{array}{c}0 \\
(0.0)\end{array}$ & $\begin{array}{c}56 \\
(19.6)\end{array}$ \\
\hline $\begin{array}{l}\text { Entrepreneur/ director/ } \\
\text { management }\end{array}$ & $\begin{array}{c}16 \\
(13.1)\end{array}$ & $\begin{array}{c}5 \\
(8.2)\end{array}$ & $\begin{array}{c}1 \\
(1.9)\end{array}$ & $\begin{array}{c}0 \\
(0.0)\end{array}$ & $\begin{array}{c}0 \\
(0.0)\end{array}$ & $\begin{array}{c}0 \\
(0.0)\end{array}$ & $1(11.1)$ & $\begin{array}{c}2 \\
(40)\end{array}$ & $\begin{array}{l}25 \\
(8.8)\end{array}$ \\
\hline Non-qualified in execution & $\begin{array}{c}0 \\
(0.0)\end{array}$ & $\begin{array}{c}1 \\
(1.6)\end{array}$ & $\begin{array}{c}2 \\
(3.7)\end{array}$ & $\begin{array}{c}4 \\
(19.0)\end{array}$ & $\begin{array}{c}0 \\
(0.0)\end{array}$ & $\begin{array}{c}0 \\
(0.0)\end{array}$ & $\begin{array}{c}1 \\
(11.1)\end{array}$ & $\begin{array}{c}0 \\
(0.0)\end{array}$ & $\begin{array}{c}8 \\
(2.8)\end{array}$ \\
\hline Semi-qualified in execution & $\begin{array}{c}26 \\
(21.3)\end{array}$ & $\begin{array}{c}19 \\
(31.2)\end{array}$ & $\begin{array}{c}38 \\
(70.3)\end{array}$ & $\begin{array}{c}8 \\
(38.1)\end{array}$ & $\begin{array}{c}0 \\
(0.0)\end{array}$ & $\begin{array}{c}0 \\
(0.0)\end{array}$ & $\begin{array}{c}2 \\
(22.2)\end{array}$ & $\begin{array}{c}0 \\
(0.0)\end{array}$ & $\begin{array}{c}93 \\
(32.6)\end{array}$ \\
\hline Qualified in execution & $\begin{array}{c}33 \\
(27.0)\end{array}$ & $\begin{array}{c}21 \\
(34.4)\end{array}$ & $\begin{array}{c}1 \\
(1.9)\end{array}$ & $\begin{array}{c}1 \\
(4.8)\end{array}$ & $\begin{array}{c}0 \\
(0.0)\end{array}$ & $\begin{array}{c}0 \\
(0.0)\end{array}$ & $\begin{array}{c}2 \\
(22.2)\end{array}$ & $\begin{array}{c}2 \\
(40)\end{array}$ & $\begin{array}{c}60 \\
(21.1)\end{array}$ \\
\hline Office services & $\begin{array}{c}3 \\
(2.5)\end{array}$ & $\begin{array}{c}3 \\
(4.9)\end{array}$ & $\begin{array}{c}4 \\
(7.4)\end{array}$ & $\begin{array}{c}2 \\
(9.5)\end{array}$ & $\begin{array}{c}1 \\
(10)\end{array}$ & $\begin{array}{c}1 \\
(33.3)\end{array}$ & $\begin{array}{c}0 \\
(0.0)\end{array}$ & $\begin{array}{c}0 \\
(0.0)\end{array}$ & $\begin{array}{c}14 \\
(4.9)\end{array}$ \\
\hline Not operational/ support & $\begin{array}{c}3 \\
(2.5)\end{array}$ & $\begin{array}{c}0 \\
(0.0)\end{array}$ & $\begin{array}{c}1 \\
(1.9)\end{array}$ & $\begin{array}{c}1 \\
(4.8)\end{array}$ & $\begin{array}{c}5 \\
(50)\end{array}$ & $\begin{array}{c}2 \\
(66.7)\end{array}$ & $\begin{array}{c}0 \\
(0.0)\end{array}$ & $\begin{array}{c}0 \\
(0.0)\end{array}$ & $\begin{array}{c}12 \\
(4.2)\end{array}$ \\
\hline Poorly defined & $\begin{array}{c}0 \\
(0.0)\end{array}$ & $\begin{array}{c}0 \\
(0.0)\end{array}$ & $\begin{array}{c}0 \\
(0.0)\end{array}$ & $\begin{array}{c}0 \\
(0.0)\end{array}$ & $\begin{array}{c}3 \\
(30)\end{array}$ & $\begin{array}{c}0 \\
(0.0)\end{array}$ & $\begin{array}{c}2 \\
(22.2)\end{array}$ & $\begin{array}{c}1 \\
(20.0)\end{array}$ & $\begin{array}{c}6 \\
(2.1)\end{array}$ \\
\hline Overall total & $\begin{array}{c}122 \\
(100)\end{array}$ & $\begin{array}{c}61 \\
(100)\end{array}$ & $\begin{array}{c}54 \\
(100)\end{array}$ & $\begin{array}{c}21 \\
(100)\end{array}$ & $\begin{array}{c}10 \\
(100)\end{array}$ & $\begin{array}{c}3 \\
(100)\end{array}$ & $\begin{array}{c}9 \\
(100)\end{array}$ & $\begin{array}{c}5 \\
(100)\end{array}$ & $\begin{array}{c}285 \\
(100)\end{array}$ \\
\hline
\end{tabular}

Note: $\mathrm{CC}=$ Capital Course; IC = Interior Course.

Among the students' families, the majority were responsible for semi-qualified occupations (32.6\%), being those which did not require technical or higher education, but only some specific practical knowledge. In the CC, the percentage of family heads with semi-qualified occupations was $33.8 \%$, and $30 \%$ in the IC.
The percentage of responsible persons with qualified occupations in the CC was $18.4 \%$ and it was $26.6 \%$ in the IC. On the other hand, the percentages of responsible persons with Planning and Organization occupations were $22.5 \%$ in the CC and $13.3 \%$ in the IC; around $40 \%$ of both the CC and IC household heads had occupations which required specific training. 
One also emphasizes that $15.7 \%$ of those responsible were in occupations which did not require any preparation for work, those classified as Non-qualified in execution, General Services, Office Services, Non-Operational/Support.

Those responsible for these work characteristics were distributed among $13.3 \%$ of the CC undergraduate families and $21.1 \%$ of the IC undergraduate families.

Table 5 below presents the household characteristics where the head of the family lives.

Table 5 - Household characteristics according to social group and Higher Education Institution - São Paulo, SP, Brazil, 2015.

\begin{tabular}{|c|c|c|c|c|c|c|c|c|c|}
\hline & \multicolumn{2}{|c|}{ GI } & \multicolumn{2}{|c|}{ G II } & \multicolumn{2}{|c|}{ G III } & \multicolumn{2}{|c|}{ G IV } & \multirow{2}{*}{$\begin{array}{c}\text { Overall } \\
\text { total }\end{array}$} \\
\hline & $\mathrm{CC}$ & IC & $\mathrm{CC}$ & IC & $\mathrm{CC}$ & IC & $\mathrm{CC}$ & IC & \\
\hline & $\begin{array}{c}\mathrm{N} \\
(\%)\end{array}$ & $\begin{array}{c}\mathrm{N} \\
(\%)\end{array}$ & $\begin{array}{c}\mathrm{N} \\
(\%)\end{array}$ & $\begin{array}{c}\mathrm{N} \\
(\%)\end{array}$ & $\begin{array}{l}\mathrm{N} \\
(\%)\end{array}$ & $\begin{array}{l}\mathrm{N} \\
(\%)\end{array}$ & $\begin{array}{l}\mathrm{N} \\
(\%)\end{array}$ & $\begin{array}{l}\mathrm{N} \\
(\%)\end{array}$ & $\begin{array}{c}\mathrm{N} \\
(\%)\end{array}$ \\
\hline Own residence & $\begin{array}{c}95 \\
(77.9)\end{array}$ & $\begin{array}{c}47 \\
(77.0)\end{array}$ & $\begin{array}{c}27 \\
(50)\end{array}$ & $\begin{array}{c}15 \\
(71.4)\end{array}$ & $\begin{array}{c}5 \\
(50)\end{array}$ & $\begin{array}{c}2 \\
(66.7)\end{array}$ & $\begin{array}{c}6 \\
(66.7)\end{array}$ & $\begin{array}{c}2 \\
(40)\end{array}$ & $\begin{array}{c}199 \\
(69.8)\end{array}$ \\
\hline 1 room & $\begin{array}{c}2 \\
(1.6)\end{array}$ & $\begin{array}{c}3 \\
(4.9)\end{array}$ & $\begin{array}{c}3 \\
(5.6)\end{array}$ & $\begin{array}{c}1 \\
(4.8)\end{array}$ & $\begin{array}{c}0 \\
(0.0)\end{array}$ & $\begin{array}{c}0 \\
(0.0)\end{array}$ & $\begin{array}{c}0 \\
(0.0)\end{array}$ & $\begin{array}{c}0 \\
(0.0)\end{array}$ & $\begin{array}{c}9 \\
(3.2)\end{array}$ \\
\hline 2 rooms & $\begin{array}{c}21 \\
(17.2)\end{array}$ & $\begin{array}{c}9 \\
(14.8)\end{array}$ & $\begin{array}{c}15 \\
(27.8)\end{array}$ & $\begin{array}{c}10 \\
(47.6)\end{array}$ & $\begin{array}{c}2 \\
(20)\end{array}$ & $\begin{array}{c}0 \\
(0.0)\end{array}$ & $\begin{array}{c}2 \\
(22.2)\end{array}$ & $\begin{array}{c}0 \\
(0.0)\end{array}$ & $\begin{array}{c}59 \\
(20.7)\end{array}$ \\
\hline 3 or more rooms & $\begin{array}{c}72 \\
(59)\end{array}$ & $\begin{array}{c}35 \\
(57.4)\end{array}$ & $\begin{array}{c}9 \\
(16.7)\end{array}$ & $\begin{array}{c}4 \\
(19)\end{array}$ & $\begin{array}{c}3 \\
(30)\end{array}$ & $\begin{array}{c}2 \\
(66.7)\end{array}$ & $\begin{array}{c}4 \\
(44.4)\end{array}$ & $\begin{array}{c}2 \\
(40)\end{array}$ & $\begin{array}{l}131 \\
(46)\end{array}$ \\
\hline Financed & $\begin{array}{l}11 \\
(9)\end{array}$ & $\begin{array}{c}6 \\
(9.8)\end{array}$ & $\begin{array}{c}6 \\
(11.1)\end{array}$ & $\begin{array}{c}2 \\
(9.5)\end{array}$ & $\begin{array}{c}2 \\
(20)\end{array}$ & $\begin{array}{c}0 \\
(0.0)\end{array}$ & $\begin{array}{c}0 \\
(0.0)\end{array}$ & $\begin{array}{c}1 \\
(20)\end{array}$ & $\begin{array}{c}28 \\
(9.8)\end{array}$ \\
\hline 1 room & $\begin{array}{c}0 \\
(0.0)\end{array}$ & $\begin{array}{c}0 \\
(0.0)\end{array}$ & $\begin{array}{c}1 \\
(1.9)\end{array}$ & $\begin{array}{c}1 \\
(4.8)\end{array}$ & $\begin{array}{c}1 \\
(10)\end{array}$ & $\begin{array}{c}0 \\
(0.0)\end{array}$ & $\begin{array}{c}0 \\
(0.0)\end{array}$ & $\begin{array}{c}0 \\
(0.0)\end{array}$ & $\begin{array}{c}3 \\
(11.1)\end{array}$ \\
\hline 2 rooms & $\begin{array}{c}7 \\
(5.7)\end{array}$ & $\begin{array}{c}3 \\
(4.9)\end{array}$ & $\begin{array}{c}4 \\
(7.4)\end{array}$ & $\begin{array}{c}1 \\
(4.8)\end{array}$ & $\begin{array}{c}1 \\
(10)\end{array}$ & $\begin{array}{c}0 \\
(0.0)\end{array}$ & $\begin{array}{c}0 \\
(0.0)\end{array}$ & $\begin{array}{c}0 \\
(0.0)\end{array}$ & $\begin{array}{c}16 \\
(5.6)\end{array}$ \\
\hline 3 or more rooms & $\begin{array}{c}4 \\
(3.3)\end{array}$ & $\begin{array}{c}3 \\
(4.9)\end{array}$ & $\begin{array}{c}2 \\
(1.9)\end{array}$ & $\begin{array}{c}0 \\
(0.0)\end{array}$ & $\begin{array}{c}0 \\
(0.0)\end{array}$ & $\begin{array}{c}0 \\
(0.0)\end{array}$ & $\begin{array}{c}0 \\
(0.0)\end{array}$ & $\begin{array}{c}1 \\
(20)\end{array}$ & $\begin{array}{c}9 \\
(3.2)\end{array}$ \\
\hline Rented & $\begin{array}{c}8 \\
(6.6)\end{array}$ & $\begin{array}{c}5 \\
(8.2)\end{array}$ & $\begin{array}{c}11 \\
(20.4)\end{array}$ & $\begin{array}{c}3 \\
(14.3)\end{array}$ & $\begin{array}{c}2 \\
(20)\end{array}$ & $\begin{array}{c}1 \\
(33.3)\end{array}$ & $\begin{array}{c}1 \\
(11.1)\end{array}$ & $\begin{array}{c}2 \\
(40)\end{array}$ & $\begin{array}{c}33 \\
(11.6)\end{array}$ \\
\hline 1 room & $\begin{array}{c}2 \\
(1.6)\end{array}$ & $\begin{array}{c}1 \\
(1.6)\end{array}$ & $\begin{array}{c}1 \\
(1.9)\end{array}$ & $\begin{array}{c}1 \\
(4.8)\end{array}$ & $\begin{array}{c}1 \\
(10)\end{array}$ & $\begin{array}{c}0 \\
(0.0)\end{array}$ & $\begin{array}{c}0 \\
(0.0)\end{array}$ & $\begin{array}{c}2 \\
(40)\end{array}$ & $\begin{array}{c}8 \\
(2.8)\end{array}$ \\
\hline 2 rooms & $\begin{array}{c}3 \\
(2.5)\end{array}$ & $\begin{array}{c}1 \\
(1.6)\end{array}$ & $\begin{array}{c}4 \\
(7.4)\end{array}$ & $\begin{array}{c}2 \\
(9.5)\end{array}$ & $\begin{array}{c}0 \\
(0.0)\end{array}$ & $\begin{array}{c}0 \\
(0.0)\end{array}$ & $\begin{array}{c}0 \\
(0.0)\end{array}$ & $\begin{array}{c}0 \\
(0.0)\end{array}$ & $\begin{array}{c}10 \\
(3.5)\end{array}$ \\
\hline 3 or more rooms & $\begin{array}{c}3 \\
(2.5)\end{array}$ & $\begin{array}{c}3 \\
(4.9)\end{array}$ & $\begin{array}{c}6 \\
(11.1)\end{array}$ & $\begin{array}{c}0 \\
(0.0)\end{array}$ & $\begin{array}{c}1 \\
(10)\end{array}$ & $\begin{array}{c}1 \\
(33.3)\end{array}$ & $\begin{array}{c}1 \\
(11.1)\end{array}$ & $\begin{array}{c}0 \\
(0.0)\end{array}$ & $\begin{array}{c}15 \\
(5.3)\end{array}$ \\
\hline Ceded & $\begin{array}{c}8 \\
(6.6)\end{array}$ & $\begin{array}{c}3 \\
(4.9)\end{array}$ & $\begin{array}{c}10 \\
(18.5)\end{array}$ & $\begin{array}{c}1 \\
(4.8)\end{array}$ & $\begin{array}{c}1 \\
(10)\end{array}$ & $\begin{array}{c}0 \\
(0.0)\end{array}$ & $\begin{array}{c}2 \\
(22.2)\end{array}$ & $\begin{array}{c}0 \\
(0.0)\end{array}$ & $\begin{array}{c}25 \\
(8.8)\end{array}$ \\
\hline 1 room & $\begin{array}{c}0 \\
(0.0)\end{array}$ & $\begin{array}{c}0 \\
(0.0)\end{array}$ & $\begin{array}{c}2 \\
(3.7)\end{array}$ & $\begin{array}{c}0 \\
(0.0)\end{array}$ & $\begin{array}{c}0 \\
(0.0)\end{array}$ & $\begin{array}{c}0 \\
(0.0)\end{array}$ & $\begin{array}{c}1 \\
(11.1)\end{array}$ & $\begin{array}{c}0 \\
(0.0)\end{array}$ & $\begin{array}{c}3 \\
(1.1)\end{array}$ \\
\hline 2 rooms & $\begin{array}{c}4 \\
(3.3)\end{array}$ & $\begin{array}{c}3 \\
(4.9)\end{array}$ & $\begin{array}{c}5 \\
(9.3)\end{array}$ & $\begin{array}{c}1 \\
(4.8)\end{array}$ & $\begin{array}{c}1 \\
(10)\end{array}$ & $\begin{array}{c}0 \\
(0.0)\end{array}$ & $\begin{array}{c}0 \\
(0.0)\end{array}$ & $\begin{array}{c}0 \\
(0.0)\end{array}$ & $\begin{array}{c}14 \\
(4.9)\end{array}$ \\
\hline 3 or more rooms & $\begin{array}{c}4 \\
(3.3)\end{array}$ & $\begin{array}{c}0 \\
(0.0)\end{array}$ & $\begin{array}{c}3 \\
(5.6)\end{array}$ & $\begin{array}{c}0 \\
(0.0)\end{array}$ & $\begin{array}{c}0 \\
(0.0)\end{array}$ & $\begin{array}{c}0 \\
(0.0)\end{array}$ & $\begin{array}{c}1 \\
(11.1)\end{array}$ & $\begin{array}{c}0 \\
(0.0)\end{array}$ & $\begin{array}{c}18 \\
(2.8)\end{array}$ \\
\hline Overall total & $\begin{array}{c}122 \\
(100)\end{array}$ & $\begin{array}{c}61 \\
(100)\end{array}$ & $\begin{array}{c}54 \\
(100)\end{array}$ & $\begin{array}{c}21 \\
(100)\end{array}$ & $\begin{array}{c}10 \\
(100)\end{array}$ & $\begin{array}{c}3 \\
(100)\end{array}$ & $\begin{array}{c}9 \\
(100)\end{array}$ & $\begin{array}{c}5 \\
(100)\end{array}$ & $\begin{array}{c}285 \\
(100)\end{array}$ \\
\hline
\end{tabular}

Note: $\mathrm{CC}=$ Capital Course; $\mathrm{IC}=$ Interior Course.

In the set of families of the two courses, those who owned their residence predominated, especially families of $\mathrm{Gl}$, which also concentrated the larger households with three or more rooms. The percentage of households in GII owning their homes was $21.4 \%$ higher in the IC compared to the CC, which has higher percentages of homes ceded, rented and financed.

Regarding the property tax receipt variable considering all families, $85.1 \%$ of families in the $\mathrm{CC}$ received collection to pay this tax and there were $91.1 \%$ of families in the IC. Households in the CC which did not receive property tax were more concentrated in GII (14.3\%), which is consistent with the housing characteristics - ceded or rented (data not shown in table).

Regarding official access to infrastructure services water, electricity and sewage - few families lived in homes without access to any of these services (7\%), most of them classified in the GIV. These data indicate that undergraduates live in areas with access to infrastructure services (data not shown in table).

Data on student scholarships or grants revealed that 64 undergraduates from the IC $(71.1 \%)$ needed some financial aid to attend university, while a percentage of $53.8 \%$ (105) of undergraduates receiving some kind of scholarship or aid was found in the CC. Of the 165 benefits, 
$24.2 \%$ (40) were housing allowance, $28.5 \%$ (47) were meal allowance, and $6.6 \%(11)$, transport allowance. Among the IC undergraduates, $35.5 \%$ (32) received scholarships or aids to pay tuition, $18.8 \%$ (17) were part of the University for All Program (PROUNI) and 5.5\% (5) used the Student Financing Program (FIES) (data not shown in table).

\section{DISCUSSION}

The two participating Higher Education Institutions use very selective admission processes, favoring students who were more likely to prepare for this process ${ }^{(9)}$.

Nursing undergraduates in this study are assumed to have more stable social conditions when compared to nursing undergraduates in other Brazilian higher education institutions.

This assumption is confirmed by both the identification of the majority of the study undergraduates belonging to social groups of greater social stability and by the comparison with the socioeconomic profiles of a sample of graduates from several Brazilian nursing courses, according to the results of the 2016 National Performance Examination of Students (ENADE) ${ }^{(10)}$.

Analyzes of 32,860 ENADE questionnaires completed by nursing graduates in Brazil showed that $61.7 \%$ had a family income of up to three minimum monthly salaries; $38.8 \%$ were the first in the family to complete college; $27.7 \%$ had a father or mother with a college degree or a postgraduate degree; $27.9 \%$ of undergraduates worked 40 hours or more weekly; $71.6 \%$ attended high school in a public school; and $23.3 \%$ entered by affirmative action or social inclusion ${ }^{(9-11)}$. Such profiles are compatible with less stable working and living conditions than those observed in the families analyzed in this study.

An analysis of variables related to the work insertion of the studied families revealed that the occupations of those responsible did not require (in most cases) higher education and did not place these workers in higher hierarchical positions in the work organization. Those responsible for these families had intermediate occupations in the working class, which means workers who are less able to negotiate wages, subject to the dynamics that govern the labor market, which generally has incomes compatible with maintaining essential family expenses ${ }^{(12)}$.

Added to this instability is the higher percentage of female household heads or the undergraduate student themself in the $\mathrm{Gll}$ of $\mathrm{Cl}$ who were mothers, since Brazilian women receive lower salaries than men on average, as the report on inequality in Brazil attests ${ }^{(13)}$. Therefore, female-headed households reflect greater instability in working and living conditions, which was observed in this study.

The social reproduction conditions of students are the basis of their possibilities to attend higher education, as shown by studies which relate objective conditions of student life and their trajectory at the university. In the process of opting for the course, it is observed that undergraduates from public education tend to choose less socially valued courses and careers with lower level of competition in entrance exams due to the higher chance of entry in detriment to the social valuation of the career ${ }^{(4,14)}$. On the other hand, most students with higher socioeconomic status who have better living conditions look for more socially prestigious courses and higher education institutions ${ }^{(3)}$.

Data analysis of medical graduates in three ENADE cycles showed that the percentage of families with an income of more than ten minimum monthly salaries is about six times higher than the Brazilian average of families in this income range ${ }^{(2)}$. Among nursing graduates in 2016 , only $2.1 \%$ of respondents' families had an income of more than ten minimum monthly salaries ${ }^{(11)}$, well below the national percentage of families in this income bracket.

The academic performance of undergraduates is also related to their social conditions $s^{(3-4,14)}$, confirming the importance of identifying the social reproduction characteristics of families for understanding the academic trajectory of students.

The results of this study showed that the best nursing courses in the country receive students from social groups which have some stability compared to undergraduates in other nursing courses in the country.

The analysis enabled one to identify nuances of this stability, expressed in the various working and living conditions of families.

In the example of the working conditions of the Gl it was found that the head of the family performed Planning and Organization occupations, those which required higher education, but also those who performed Qualified occupations for which technical training is sufficient. Among the heads of families classified in the Gll, those with semi-qualified occupations stood out, which requires a preparatory course. However, they performed occupations unrelated to their field of education and, despite having stable ties, largely held less prestigious positions in the labor market.

It is noteworthy that even between these two social groups, which present higher stability gradients, it was identified that those responsible for occupations which did not require work preparation promoted families with greater instability gradients, both in the characteristics of employment relationships and the income and other benefits arising from work.

Although most families of nursing undergraduates in this study have more stable living conditions (Gl and GII), the percentage of families with higher working and living precariousness (GIII and GIV) is not negligible.

Therefore, the study enabled one to identify a social heterogeneity of student groups, both internally within each group and between social groups.

The study has the limitation that it was conducted with students from two universities which lead the best rankings in the country. Thus, one suggests conducting further studies which take different realities into account in order to identify social reproduction characteristics of students from other nursing courses. 


\section{CONCLUSION}

Although most families were classified into the most socially stable groups ( $\mathrm{Gl}$ and $\mathrm{GII})$, which would be expected among young people who entered the Universities of this study, the analysis of social reproduction of the families of the undergraduate students of the two courses through the SRI exposed stability gradients which are compatible with intermediate social strata.

The study demonstrated the dynamics which exist in social reality, surpassing more static characterizations found in studies that fragment reality in sociodemographic data described separately and independently.

This dynamism was captured by the SRI, an instrument which enables both overcoming social classifications elaborated from socioeconomic indicators and identifying characteristics of social stability/instability, always conditioned by the inseparable double face of the phenomenon - the life of nursing undergraduate families.

The sensitivity of the instrument used for social classification (SRI) made it possible to identify social strata subgroups with greater stability in the social reproduction conditions (Gl and GII) among the undergraduate nursing students, which articulates variables related to working and living conditions, in turn showing the dynamic relationship between them.

This study presents challenges for the university regarding recognizing the social profiles of students in the various courses, with a view to identify social instabilities and to elaborate policies for strengthening them, both those which improve aspects of affirmative policies and those which promote guidelines for student permanence in the university. It also poses the challenge of transforming the historically grounded academic training of maintaining the status quo of the elite.

\section{RESUMO}

Objetivo: Identificar características de reprodução social das famílias de graduandos de enfermagem. Método: Estudo de abordagem quantitativa, transversal descritivo, realizado em dois cursos de bacharelado em enfermagem, um público e um privado, no estado de São Paulo. Resultados: Participaram 285 estudantes, sendo 195 do curso público e 90 do privado, que responderam a um questionário para classificação dos perfis de reprodução social. Foram identificados quatro grupos com condições sociais distintas. Embora a maior parte das famílias tivesse condições estáveis de vida, a porcentagem de famílias com precarização nas condições de trabalho e de vida não era desprezível. Conclusão: A análise da reprodução social das famílias dos graduandos dos dois cursos expôs gradientes de estabilidade compatíveis com estratos sociais intermediários.

\section{DESCRITORES}

Estudantes de Enfermagem; Classe Social; Condições Sociais; Educação Superior.

\section{RESUMEN}

Objetivo: Identificar características de reproducción social de familias de estudiantes de enfermería. Método: Estudio cuantitativo, transversal, descriptivo, realizado en dos cursos de pregrado en enfermería, uno público y otro privado, en el estado de São Paulo. Resultados: Participaron 285 estudiantes, 195 del curso público y 90 del curso privado, quienes respondieron un cuestionario para clasificar los perfiles de reproducción social. Se identificaron cuatro grupos con diferentes condiciones sociales. Aunque la mayoría de las familias tenían condiciones de vida estables, el porcentaje de familias con condiciones de trabajo y de vida precarias no resultó despreciable. Conclusión: El análisis de la reproducción social de las familias de los estudiantes de los dos cursos expuso gradientes de estabilidad compatibles con estratos sociales intermedios.

\section{DESCRIPTORES}

Estudiantes de Enfermería; Clase Social; Condiciones Sociales; Educación Superior.

\section{REFERENCES}

1. Massi L, Muzzeti LR, Suficier DM. A pesquisa sobre trajetórias escolares no Brasil. Rev Ibero Am Estudos Educ. 2017;12(3):1854-73.

2. Ristoff D. O novo perfil do campus brasileiro: uma análise do perfil socioeconômico do estudante de graduação. Avaliação (Campinas) 2014;19(3):723-47.

3. Palazzo J, Gomes CA. Origens sociais dos futuros educadores: a democratização desigual da educação superior. Avaliação (Campinas). 2012;17(3):877-98.

4. Lima Junior P, Ostermann F, Rezende F. Análise dos condicionantes sociais do sucesso acadêmico em cursos de graduação em física à luz da sociologia de Bourdieu. Ens Pesqui Educ Ciênc. 2013;15(1):113-29.

5. De Sordi MRL, Malvazi MMS. As duas faces da avaliação: da realidade à utopia. Rev Educ PUC (Campinas). 2004;17:105-15.

6. Viana N, Soares CB, Campos CMS. Reprodução social e processo saúde-doença: para compreender o objeto da Saúde Coletiva. In: Soares CB, Campos CMS, organizadoras. Fundamentos de saúde coletiva e o cuidado de enfermagem. Barueri: Manole; 2013. p. 107-42.

7. Arruda MSB, Soares CB, Trapé CA, Cordeiro L. Crackland: beyond crack cocaine. Soc Med. 2017;11(1):8-17.

8. Brasil. Ministério do Trabalho e do Emprego. Classificação Brasileira de Ocupações [Internet]. Brasília; 2018 [citado 2018 abr. 15]. Disponível em: http://www.mtecbo.gov.br/cbosite/pages/home.jsf

9. Ristoff D; Grupo Estratégico de Análise da Educação Superior no Brasil. Perfil socioeconômico do estudante de graduação: uma análise de dois ciclos completos do Enade (2004 a 2009). Cad GEA [Internet]. 2013 [citado 2018 out. 11];2(4). Disponível em: http://flacso.redelivre.org.br/ files/2015/03/Caderno_GEA_N4.pdf

10. Brasil. Ministério da Educação; Instituto Nacional de Estudos e Pesquisas Educacionais Anísio Teixeira. Relatório síntese de área enfermagem Brasília; 2016. 
11. Brasil. Ministério da Educação; Instituto Nacional de Estudos e Pesquisas Educacionais Anísio Teixeira. Censo da educação superior 2015. Brasília; 2016.

12. Santos JAF, Ribeiro LVF. Emprego, estratificação e desigualdade. Estud Av. 2016;30(87): 89-102.

13. Oxfam Brasil. A distância que nos une: um retrato das desigualdades brasileiras [Internet]. São Paulo: 2017 [citado 2018 out. 11 ]. Disponível em: https://www.oxfam.org.br/sites/default/files/arquivos/relatorio_a_distancia_que_nos_une.pdf

14. Ferreira DM, Silva MEL. Condições objetivas e investimentos acadêmicos dos estudantes do ensino superior. Educ Soc. 2015;36(130):101-15. 